\title{
Ovarian dermoid presenting as unilateral obstructive uropathy
}

\author{
Sankar Neelakantan, Ravikanth Reddy, Anil Kumar Swamy
}

Department of Radiology, St. Johns Medical College and Hospital, Bangalore, Karnataka, India

\section{Correspondence to} Dr Sankar Neelakantan, dr.sankar@live.com

Accepted 6 July 2016

\section{(a) CrossMark}

To cite: Neelakantan $S$, Reddy R, Swamy AK. BMJ Case Rep Published online: [please include Day Month Year] doi:10.1136/bcr-2016216878

\section{DESCRIPTION}

A 17-year-old female patient presented to the emergency department with history of intermittent right sided colicky abdominal pain and nausea since 3 weeks. Urine analysis revealed no evidence of infection. She was referred for imaging workup, which included an abdominal ultrasound examination that revealed right sided mild hydroureteronephrosis, but the distal ureter could not be visualised due to poor acoustic window. However, a vague right adenexal cystic lesion (figure 1) was noted and a CT scan was advised to characterise the lesion and to assess the cause for the obstructive uropathy.

CT scan of the abdomen and pelvis was performed which revealed a well-defined right adenexal lesion with intralesional fat (hounsfield unit (HU) -90) and calcification involving the right

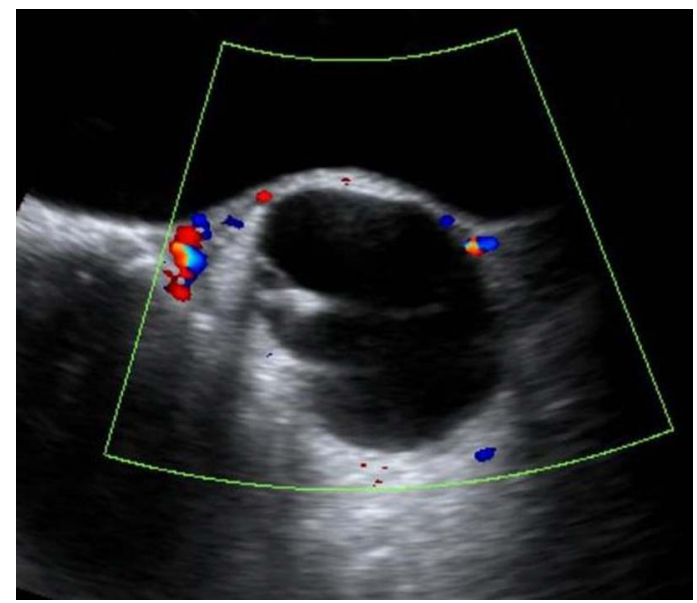

Figure 1 Ultrasound image showing an anechoic adenexal cystic lesion with no septations, mural components or internal vascularity.

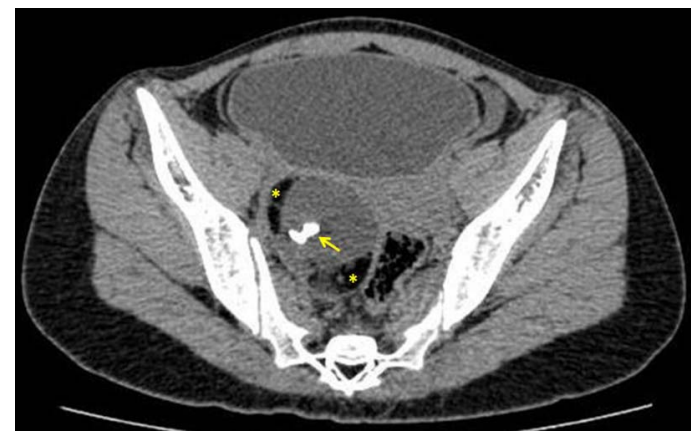

Figure 2 Axial non-enhanced CT section showing a well-defined right ovarian lesion with intralesional fat (asterisk) and calcifications (arrow). ovary which was diagnosed as an ovarian dermoid. The right ovarian dermoid was noted adjacent to the distal ureter causing its compression, resulting in right sided hydroureteronephrosis. No intraluminal ureteric calculi were noted (figures 2-4).

The dermoid cyst was surgically confirmed and patient underwent a right oophorectomy following which the patient's symptoms completely resolved. Histopathology of the lesion confirmed that it was an ovarian dermoid.

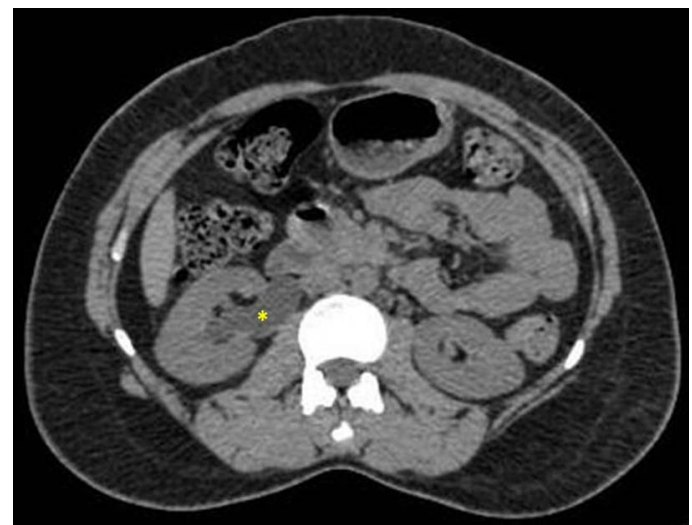

Figure 3 Axial non-enhanced CT section showing right hydroureteronephrosis (asterisk).

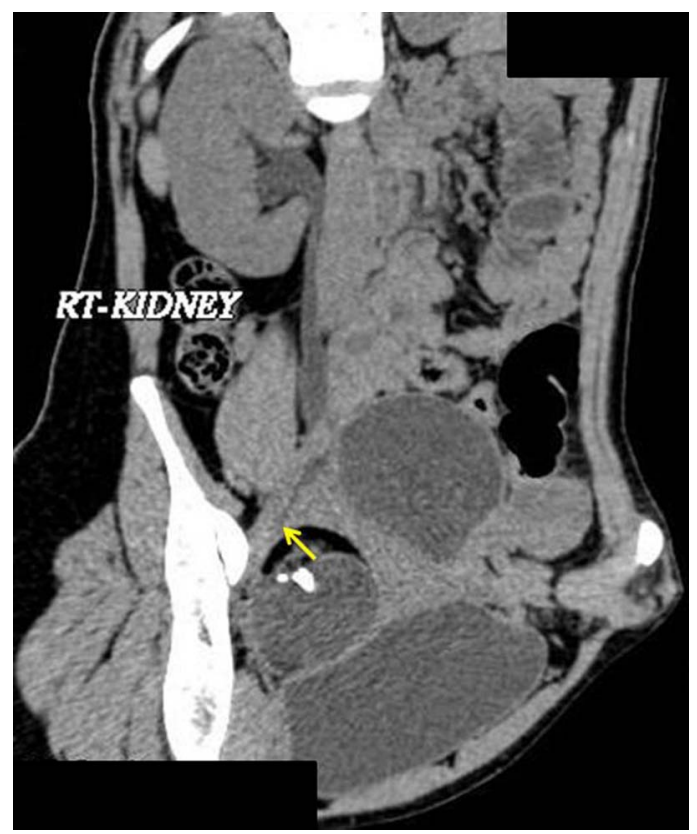

Figure 4 Oblique coronal reformatted non-enhanced CT image showing right ovarian dermoid causing obstructive right hydroureteronephrosis (arrow). RT, right. 
Dermoid cysts are the most common ovarian neoplastic lesions found in adolescents. These masses are a benign type of germ cell tumours that arise from totipotent cells in the ovary which develop into fully differentiated ectodermal, mesodermal and endodermal tissues. ${ }^{1}$ Fat attenuation within a cyst, with or without calcification in the wall, is diagnostic for dermoid cyst. Fat is reported in $93 \%$ of cases and teeth or other calcifications

\section{Learning points}

Dermoids are the most common ovarian tumours in younger patients which develop from fully differentiated ectodermal, mesodermal and endodermal components.

- Ovarian dermoids should be considered in the differential diagnosis of distal ureteric obstruction causing proximal hydroureteronephrosis in young female patients.

- Intratumorous fat of dermoid cysts shows negative attenuation on non-enhanced CT and is a highly specific diagnostic finding. in $56 \% .^{2}$ Ovarian dermoids are associated with complications including torsion, rupture, ureteric obstruction, infection and malignant transformation. These complications require different management strategies, therefore timely and accurate diagnosis is important for optimal patient care. ${ }^{3}$

Non-enhanced CT has higher sensitivity in detecting distal ureteric calculi and has the advantage of detecting extraurinary retroperitoneal and pelvic masses that cause ureteral compression as was the case with this patient.

Twitter Follow Sankar Neelakantan at @drsankar23

Competing interests None declared.

Patient consent Obtained.

Provenance and peer review Not commissioned; externally peer reviewed.

\section{REFERENCES}

1 Powell J. Benign adnexal masses in the adolescent. Adolesc Med 2004;15:535-47.

2 Comerci JT Jr, Licciardi F, Bergh PA, et al. Mature cystic teratoma: a clinico pathologic evaluation of 517 cases and review of the literature. Obstet Gynecol 1994;84:22-8.

3 Buy JN, Ghossain MA, Moss AA, et al. Cystic teratoma of the ovary: CT detection. Radiology 1989;171:697-701.

Copyright 2016 BMJ Publishing Group. All rights reserved. For permission to reuse any of this content visit http://group.bmj.com/group/rights-licensing/permissions.

BMJ Case Report Fellows may re-use this article for personal use and teaching without any further permission.

Become a Fellow of BMJ Case Reports today and you can:

- Submit as many cases as you like

- Enjoy fast sympathetic peer review and rapid publication of accepted articles

- Access all the published articles

- Re-use any of the published material for personal use and teaching without further permission

For information on Institutional Fellowships contact consortiasales@bmjgroup.com

Visit casereports.bmj.com for more articles like this and to become a Fellow 